\title{
Child Development and Nutritional Status of Children Under Five: A Cross-Sectional Study of a Fishermen Community in Terengganu, Malaysia
}

\author{
Badriah Aisyah Bahtiar, Asma' Ali", Hayati Mohd Yusof, Khairil Shazmin Kamarudin \\ Department of Food Sciences, Faculty of Fisheries and Food Science, Universiti Malaysia Terengganu, \\ 21030 Kuala Nerus, Terengganu, Malaysia
}

\begin{abstract}
This study aims to determine child development, nutritional status and the association between child development and nutritional status. This cross-sectional study was conducted among 60 fishermen's children under five years old in selected districts in Terengganu. All respondents were assisted by their mothers during the assessment. Child development was evaluated through the Denver II Development Screening Test. Nutritional status was determined via the anthropometry assessment (BMI-for-age and height-for-age). Preponderantly, the prevalence of suspected development delay of children under-five in Terengganu was $31.7 \%$. The prevalence of suspected delay for language, fine motor-adaptive, and personal-social skills were $15.0 \%, 1.7 \%$, and $16.7 \%$, respectively. BMI-for-age z-score and heightfor-age $\mathrm{z}$-score of these children were $-1.62 \pm 1.23$ and $-0.27 \pm 1.41$, respectively, indicating a normal range; nonetheless, there were still children that were wasted $(23.3 \%)$, severely wasted $(13.3 \%)$, stunted $(5.0 \%)$, severely stunted $(1.7 \%)$, and at risk of being overweight $(1.7 \%)$. However, the chi square test showed there was no association found between child development and nutritional status, BMI-for-age and height-for-age ( $p>0.001)$, among fishermen's children under-five in this study. The nutritional status had no effect on the development of these fishermen's children, but may have been influenced by other factors such as stimulating surroundings, parenting abilities, and culture.
\end{abstract}

Keywords: child development, children under five years, fishermen, nutritional status

\section{INTRODUCTION}

Extant research recognizes early child development's critical role in a person's imminent trajectory and life course (Huiracocha-Tutiven et al.2019). An increasing body of evidenceindicates that children from low-income families have slightly slowed development growth (Grantham et al. 2014; Rao et al. 2019; Rubio-Codina et al. 2016). Child development has received much too little attention in these low-income households, especially in fishing communities, until now. Floods and monsoon seasons affect this community's income, particularly in Terengganu, resulting in inadequate food supplies and damaged infrastructure, leading to food shortages, poor nutrition, and health issues (Capanzana et al. 2018; FAO 2000; Sanusi et al. 2018; Atiah \& Asma' 2021). Although most Terengganu fishermen's household income was over the poverty level, they still lacked health, education, and insurance (Chua et al. 2018; Wei
\& Ali 2018; Sanusi et al. 2018). The majority of the parents and children in this neighbourhood only completed secondary school (Wong et al. 2014). In terms of occupation, the majority were occupied in fishing, while some were involved in agricultural or labour activities. As for their wives, more than half of them were unemployed and worked as housewives in Terengganu (Wei \& Ali 2018; Wong et al. 2014).

Child developmental delay is the inability of children under the age of five to reach developmental milestones associated with cognitive and motor disabilities, resulting in limitations in life activities (NHMS 2016b). In 2016, the incidence of developmental delay among these children ranged from $5 \%$ to $16 \%$ worldwide, depending on environmental and genetic factors. In 2015, the prevalence of overall developmental delay in children in Malaysia was $3.3 \%$. The prevalence of developmental delay in speech, social skills, fine motor, and gross motor was $1.7 \%, 1.2 \%, 0.7 \%$, and $0.6 \%$, respectively,

\footnotetext{
"Corresponding Author: tel: +609-6684969, email: asma.ali@umt.edu.my

(Received 29-04-2021; Accepted 07-07-2021; Published 29-07-2021)
} 
at the national level. There was also a higher incidence of developmental delay in children whose mothers had low educational levels and whose parents were unemployed (NHMS 2016b). This demonstrates the significance of a family's socioeconomic status in a child's growth.

The national prevalence of underweight, stunting, and wasting in Malaysia in 2015 was $13 \%$, $13.4 \%$, and $7.9 \%$ for these children, respectively (NHMS 2015). Meanwhile children under the age of five in rural areas had a higher prevalence of stunting and a lower prevalence of wasting than children in urban areas (NHMS 2015). A comparable study conducted in 2016 discovered that the national prevalence of underweight climbed to $13.7 \%$ among children under the age of five, the national prevalence of stunting increased swiftly to $20.7 \%$, and the national prevalence of wasting increased marginally to $11.5 \%$ (NHMS 2016b). According to UNICEF Malaysia (2018), stunting among children under five increased alarmingly from 2006 to 2016 , rising from $17.7 \%$ to $20.7 \%$. According to these three reports, the prevalence of underweight, stunting, and wasting among Malaysian children under five has grown, signaling the need for intervention initiatives to reduce its prevalence. More recently, research has been published that indicates a clear correlation between child development and nutritional status. According to studies, when a child's nutritional condition is excellent, its growth is more substantial (Huiracocha-Tutiven et al. 2019; Hurley et al. 2016; Jimoh et al. 2018; Warsito 2012). Malnutrition affects a child's growth because the body is unable to develop due to a lack of nutrition (Capanzana et al. 2018). Terengganu had among the highest rate of stunting in 2016 , at $26 \%$, which was significantly higher than the national rate of $13.4 \%$ (UNICEF 2018). The growing incidence of stunting in Malaysia, especially in Terengganu, is concerning because it will have a negative impact on children's future health because they are still in the critical growth stage. Additionally, there is a dearth of knowledge on Terengganu children's growth and a scarcity of data on the nutritional status of children under the age of five living in fishing communities in Terengganu. Thus, in light of the aforementioned issues, it is critical to conduct this study on child development and its relationship to nutritional status among fishermen's children under the age of five in Terengganu. In keeping with the aims of the study, the following research question was addressed: Is there any significant relationship between child development and nutritional status among fishermen's children under the age of five in this study? The hypothesis for this study is that children under the age of five who live in lowincome households have poor child development and nutritional status.

\section{METHODS}

\section{Design, location and time}

This cross-sectional study was conducted in Kuala Nerus and Kuala Terengganu (these two districts in Terengganu reside a large number of fishermen). The respondents involved were voluntarily mothers, and had healthy children aged 2 years to 4 years 11 months old from a fishermen household. Ethical approval was obtained by the Human Ethics Board of Committees of Universiti Malaysia Terengganu with reference number: JKEPM/2019/37.

\section{Sampling}

According to the Malaysian Open Data Portal (2019), the total population of Kuala Terengganu and Kuala Nerus in 2016 was 367,600 , while the number of children aged 0 to under five years old was 38,000 in both districts, accounting for $10.33 \%$ of the total population. Meanwhile, the total number of fishermen in Kuala Terengganu and Kuala Nerus in 2016 was 2,567. This study covers a selected population to match the purpose of the study, with responses ranging in age from 2 years to under five years. The children in this age group were chosen for consistent and accessible anthropometric measurement since they can stand without the assistance of others for the determination of nutritional status.

Respondents are excluded from this study if they are under two years old considering them as infants. As the age range is further lowered to 2 to under five, the possibilities of obtaining respondents are further lessened. Due to the scarcity of respondents who met the criteria, healthy 2 to 5-year-old children from the fisherman community, snowball sampling was used. Researchers went to each fisherman's ports in these districts and asked the fishermen if they knew of any eligible candidates to find a suitable candidate. The chosen respondents were also asked if they knew any other qualified people for 


\section{Child development and nutritional status of children under five}

future data gathering. Given the $95 \%$ confidence interval, and the prevalence of stunting of children under five in Terengganu was $20.7 \%$ (UNICEF 2018), the minimum sample size derived from Cochran's formula was 60 respondents. Data was collected between July to October 2019.

\section{Data collection}

The data was collected via home visits to fishermen homes. The subjective information sheet and informed consent were given to the respondents' moms before data collection. Once mothers agreed to participate voluntarily, a questionnaire was to mothers. In Section 1 , the moms were given questionnaires to collect information about their socio-economic situation. The researchers then measured the respondent's weight and height, which were reported in Section 2. Following that, in Section 3 , researchers interviewed mothers about their child's development. A token of appreciation was handed at the end of the session. The questionnaire consists of three sections: 1- Socioeconomic status; 2- Child development (Denver II Development Screening Test); and 3- Nutritional Status (BMI-for-age z-score and height-for-age $\mathrm{z}$-score). It was administered during a face-toface interview with parents and their children.

Meanwhile, for child development, the parameters used were gross motor, language, fine motor-adaptive, and personal-social skills. The children were assessed on their ability to perform certain items or activities by listening to the researcher's instructions or parents. The questions were adapted from the Ministry of Health's Baby and Children Health Records book and the National Health and Morbidity Survey questionnaire (NHMS 2016a). The scoring system and interpretation were based on the Denver II Development Screening Test. Denver II Development Screening Test is solely for screening purposes to detect whether the child is suspected of delay in development. Therefore, it does not utterly confirm that a child is indeed delayed. Normal indicates that the child is undergoing normal development with no delays for their age. Suspect indicates that there is a probability of the child undergoing delay in development for their age and are recommended to see an expert for re-screening.

The children's weight and height were measured using an electronic weighing scale (Tanita Bioelectrical Impedance Analysis BC-
541, Japan) and SECA portable stadiometer 225 (SECA, Hamburg, Germany), respectively. Without shoes, the respondent stands upright with arms at his sides, feet together, and heels and back against the wall. The measurement should be taken from a line drawn on Plexiglas and should be accurate to within $0.5 \mathrm{~cm}$. Ascertain that the weighing scale is on a flat, hard surface and that it reads zero when there is no weight. The respondent is measured when dressed in light clothing and without shoes. Weight measurements should be taken to the nearest 0.1 $\mathrm{kg}$. The measurement taken was analyzed using a WHO Anthro version 3.2.2 software to assess the children's nutritional status in z-score (BMI-forage and height-for-age). The child's BMI-for-age was calculated using $\mathrm{z}$-scores to decide if he or she is overweight, obese, or wasting. The heightfor-age z-scores are used to decide whether a child is stunted. The height-for-age and BMI-forage indicators were determined using the WHO (2006) cut-off points. When the reading is $>3$ SD $\mathrm{z}$-score, the child is classified as tall for his or her age or obese for BMI-for-age. When a child's reading score is greater than 1 or $2 \mathrm{SD}$ in z-scores, he or she could be at risk of being overweight or obese, respectively (for BMI-for-age). Meanwhile, if the height-for-age z-score reading falls below -2 or -3 SD, the children are classified as stunted or severely stunted, respectively. In terms of BMI-for-age z-scores, children who fall below the -2 and -3 SD z-scores, respectively, are considered to be wasting.

\section{Data analysis}

The SPSS (IBM SPSS Statistics for Windows, Version 23) was used with the significance level of $\mathrm{p}<0.05$. A normality test was carried out before data analysis. Descriptive data for socio-demographic characteristics, child development and nutritional status was calculated in terms of mean, median, frequency, percentage, standard deviation, and interquartile range. Chisquare test was used to determine the association between child development and nutritional status of fishermen's children under-five, significant at $\mathrm{p}<0.05$.

\section{RESULTS AND DISCUSSION}

\section{Sociodemographic data}

Among the 60 respondents, $30(50.0 \%)$ were boys, while the remaining $30(50.0 \%)$ 
were girls. All of the respondents were Malay $60(100.0 \%)$ and Muslim $60(100.0 \%)$, as shown in Table 1. Majority were aged 3 years - 4 years 11 months $(\mathrm{n}=35,58.3 \%)$ followed by 2 years 2 years 11 months $(n=25,41.7 \%)$. Most of the parents had a secondary school education $(78.3 \%)$. Monthly household incomes are typically less than RM1,500 (93.3\%), with households of 5 to 8 family members $(46.7 \%)$, and more than half reported not receiving any financial aid $(55.0 \%)$. Overall, the sociodemographic status of fishermen's households in Kuala Nerus and Kuala Terengganu is low. In the majority of these families, the parents' highest standard of schooling was just secondary school. It's upsetting because education is so important in everyone's life. It's also worrying because children have a proclivity to follow in their parents' footsteps. Higher education contributes to higher earnings, which can improve their socioeconomic status by raising their monthly household income by at least RM1,000. Furthermore, most mothers of the respondents were housewives who depended solely on their husbands' income.

\section{Child development of the children}

The parameters employed in this child development assessment were based on gross motor, language, fine motor-adaptive, and personal-social skills. The majority of respondents had a normal overall development $(n=41,68.3 \%)$. The suspected development delay was $31.7 \%$ $(n=19)$ in this study, which is considered to be comparatively high in comparison to studies conducted in Malaysia (3.3\%) (NHMS 2016b), in Norway (5.7\% to $7.0 \%$ ) (Valla et al. 2015), in the United Arab Emirates (8.4\%) (Eapen et al. 2006), and in Ecuador (11.7\%) (Huiracocha-Tutiven et al. 2019). It is likely that the findings of these studies were affected by the techniques used in the various studies. The Denver Development Screening Test was used in this study, while other studies have used the New Child Health Record Book (NHMS 2015), the Schedule of Growing Skills II (Jimoh et al. 2018), and the Ages and Stages Questionnaire (Valla et al. 2015; Zhang et al. 2018). Two critical factors may have contributed to this suspected developmental delay among fishermen's children in this study: socioeconomic status and parenting skills. These respondents live in households with a low socioeconomic status, which is considered to have a negative effect on children's growth (Grantham et al. 2014; Rao et al. 2019; RubioCodina et al. 2016; Treanor et al. 2012) due to the fact that poverty can result in cognitive and behavioural delays (UNICEF 2018; Shong et al. 2018). Numerous studies have found that socioeconomic status (i.e., income and education) has the greatest negative effect on child growth (Grantham et al. 2014; Rao et al. 2019; RubioCodina et al. 2016; Treanor et al. 2012).

The prevalence of suspected developmental delay in gross motor and fine motor skills was $0.0 \%$ and $1.7 \%$, respectively, among fishermen children under the age of five in Kuala Nerus and Kuala Terengganu. This result is consistent with NHMS (2016), which found that the prevalence of developmental delay in gross motor skills was $0.6 \%$ and $0.7 \%$ respectively, among Malaysian children. Contradicts to a finding by Duarte et al. (2017), children from low-income households have a higher risk of motor developmental delay. Given that the fishermen's children came from low-income families $(93.3 \%$ came from households earning less than RM1500 per month), it is impressive that their motor production was not delayed. Duarte et al. (2017) stated that the atmosphere in which children grow plays a role in their motor growth, with the more stimulation in their immediate environment, the more developed their motor skills (Duarte et al. 2017). This statement is confirmed by Venetsanou and Kambas (2010), who discovered that positive environmental benefits these children's motor growth, especially gross motor development. Additionally, they noted that a household's low socioeconomic status results in a lack of available space and a lack of variety of toys, which can have a negative effect on motor growth (Venetsanou \& Kambas 2010). Toys, such as building blocks, may assist children in improving their fine motor-adaptive skills. In comparison, children in fishermen households may have a low income and live in a small home, but they have access to spacious outdoor areas such as the playground, the yard, and the beach. Additionally, they may lack toys, but they are exposed to other resources that can be used to play, such as tag and chase, hide and seek, or building structures with sand to improve motor skills (Venetsanou \& Kambas 2010), which may explain why some of them advanced in gross motor $(5.0 \%)$ and fine motor-adaptive $(33.3 \%)$ growth. Additionally, 


\section{Child development and nutritional status of children under five}

Table 1. Sociodemographic characteristics of under five and respondents in Terengganu $(\mathrm{n}=60)$

\begin{tabular}{|c|c|c|}
\hline \multirow[b]{2}{*}{ Characteristics } & Distribution & \multirow{2}{*}{$\begin{array}{c}\text { Mean } \pm \mathrm{SD} / \\
\text { Median } \\
(\mathrm{IQR})\end{array}$} \\
\hline & $\mathrm{n}(\%)$ & \\
\hline \multicolumn{3}{|l|}{ Gender } \\
\hline Boy & $30(50.0)$ & \\
\hline Girl & $30(50.0)$ & \\
\hline \multicolumn{3}{|l|}{ Race } \\
\hline Malay & $100(100.0)$ & \\
\hline \multicolumn{3}{|l|}{ Religion } \\
\hline Islam & $100(100.0)$ & \\
\hline Age & & $\begin{array}{c}37.93 \pm 10.49 \\
\text { months }\end{array}$ \\
\hline 2 years -2 years 11 months & $25(41.7)$ & \\
\hline 3 years -4 years 11 months & $35(58.3)$ & \\
\hline \multicolumn{3}{|l|}{ Highest education level (Mother) } \\
\hline Primary school & $7(11.7)$ & \\
\hline Secondary school & $47(78.3)$ & \\
\hline Certificate/STPM/Diploma & $4(6.7)$ & \\
\hline Degree/Higher education & $2(3.3)$ & \\
\hline \multicolumn{3}{|l|}{ Highest education level (Father) } \\
\hline No formal education & $2(3.3)$ & \\
\hline Primary school & $11(18.3)$ & \\
\hline Secondary school & $44(73.3)$ & \\
\hline Certificate/STPM/Diploma & $3(5.0)$ & \\
\hline Number of family members & & $5(3)$ \\
\hline $1-4$ & $25(41.7)$ & \\
\hline $5-8$ & $28(46.7)$ & \\
\hline$>9$ & $7(11.7)$ & \\
\hline \multicolumn{3}{|l|}{ Monthly household income } \\
\hline$\leq \mathrm{RM} 1,500$ & $56(93.3)$ & \\
\hline RM1,500-RM2,999 & $4(6.7)$ & \\
\hline \multicolumn{3}{|l|}{ Mother's occupation } \\
\hline Run small business & $2(3.3)$ & \\
\hline Store assistant & $3(5.0)$ & \\
\hline Caregiver & $1(1.7)$ & \\
\hline Housewife & $50(83.3)$ & \\
\hline Others & $4(6.7)$ & \\
\hline \multicolumn{3}{|l|}{ House ownership } \\
\hline Bought & $3(5.0)$ & \\
\hline Rent & $12(20.0)$ & \\
\hline $\begin{array}{l}\text { Owned or } \\
\text { passed down by parents }\end{array}$ & $45(75.0)$ & \\
\hline \multicolumn{3}{|l|}{ Financial aid receiver } \\
\hline Yes & $27(45.0)$ & \\
\hline No & $33(55.0)$ & \\
\hline \multicolumn{3}{|l|}{ Food aid receiver } \\
\hline Yes & $2(3.3)$ & \\
\hline No & $58(96.7)$ & \\
\hline
\end{tabular}

RM: Ringgit Malaysia
Duarte et al. (2017) discovered that children who have more siblings have greater gross motor development than children who have fewer siblings. The median number of family members in a fishermen's household was five, suggesting that most of them have siblings to play with, which aids in gross motor growth. This will account for the fishermen's children's superior motor growth. As seen in Table 2, both language development $(\mathrm{n}=9,15.0 \%)$ and personal social skills $(n=10,16.7 \%)$ faced substantial delays. This, however, contradicts the results of a previous national survey, which showed that only $1.7 \%$ of children had a delay in language development (NHMS 2016b). There are several possible reasons for this contradiction, including the sample size, respondents' sociodemographic characteristics, and respondents' age. The previous study was a large-scale study that included respondents from a number of sociodemographic backgrounds and a wide range of ages. Numerous previous studies established a strong correlation between language development and socioeconomic status, and home climate (Rubio-Codina et al. 2016; Bradley et al. 2002; Pem 2015). This is because parents of low socioeconomic status are less likely to purchase products that encourage brain growth, such as reading and learning materials. Additionally, they frequently have no say about how much time their children spend watching television. Parenting abilities are a factor in a child's language growth (Bradley et al. 2002). Communicating with and engaging in simple activities with their children, such as reading, will aid in brain development, including language development (Bradley et al. 2002).

As shown, the prevalence of suspected personal social skills development delay in fishermen's children was $16.7 \%$. This research contradicts the results in NHMS (2016b), which suggested a substantially lower prevalence of social skill developmental delay among children in Malaysia (1.2\%). Personal social skills refer to children's ability to care for themselves (e.g., putting on or removing clothes independently) and social skills (such as making friends and playing with anyone). However, few studies exist that examine the factors influencing children's development of personal social skills, primarily since most studies classified self-care as a fine motor skill. Though, there is an explanation for the high prevalence of suspected development of 
personal social skills among fishermen's children. According to Venetsanou and Kambas (2010), cultures often play a role in child growth, as various cultures emphasize different development aspects while undermining others.

\section{Nutritional status of the children}

As shown in Table 3, these children's BMI-for-age and height-for-age $z$-scores were $-1.62 \pm 1.23$ and $-0.27 \pm 1.41$, respectively, implying normal BMI and height. In Table 3, the fact that approximately $36.6 \%$ of respondents were wasted or severely wasted stands out. This study showed that the prevalence of wasting was higher than the national prevalence of $11.5 \%$ to $20.7 \%$ (NHMS 2015; NHMS 2016b). Wasting occurs when a child's BMI-for-age falls below -2SD of the WHO z-score for growth development, according to the World Health Organization (1997). It is often linked to acute and/or severe disease, as well as chronic unfavourable conditions like inadequate hygiene, which may make children more susceptible to disease. Low daily energy intake, particularly during the monsoon season, is one possible explanation for our findings, which can lead to wasting. During the monsoon season, about $98.8 \%$ of the fishermen households in Terengganu were severely food insecure, and the remainder were moderately food insecure, according to a study conducted by Sanusi et al. (2018) in Terengganu. Food coping mechanisms were most widely used in the Sanusi study by reducing the amount of food cooked for meals and decreasing daily/monthly food expenditure. As a consequence, it's likely that wasting would occur among the children in this sample.

However, there are other possible explanations for the higher prevalence of wasting in this study. Prior studies have noted the importance of a mother's education and practices (Bandoh et al. 2018; Capanzana et al. 2018; Cheah et al. 2012; Khan et al. 2019; Mzumara et al. 2018). The prevalence of wasting was shown to be strikingly higher among mothers with lower education level (Adnan \& Muniandy 2012). A study discovered that mothers with low BMI during pregnancy have a greater risk of having wasting and underweight children (Khan et al. 2019). These findings may be somewhat limited by the nutritional status of mothers during their pregnancy. Low income is one of the key factors in poor nutritional status since they have
Table 2. Overall child development and it's parameter among under five children in Trengganu $(\mathrm{n}=60)$

\begin{tabular}{|c|c|}
\hline Items & $\begin{array}{c}\text { Distribution } \\
\mathrm{n}(\%)\end{array}$ \\
\hline \multicolumn{2}{|l|}{ Overall development } \\
\hline Normal $^{\mathrm{a}}$ & $41(68.3)$ \\
\hline Suspect ${ }^{\mathrm{b}}$ & $19(31.7)$ \\
\hline \multicolumn{2}{|l|}{ Gross motor } \\
\hline Advanced & $3(5.0 \%)$ \\
\hline Normal & $57(95.0 \%)$ \\
\hline Caution & $0(0.0 \%)$ \\
\hline Delayed & $0(0.0 \%)$ \\
\hline \multicolumn{2}{|l|}{ Language } \\
\hline Advanced & $0(0.0 \%)$ \\
\hline Normal & $50(83.3 \%)$ \\
\hline Caution & $1(1.7 \%)$ \\
\hline Delayed & $9(15.0 \%)$ \\
\hline \multicolumn{2}{|l|}{ Fine motor-adaptive } \\
\hline Advanced & $20(33.3 \%)$ \\
\hline Normal & $39(65.0 \%)$ \\
\hline Caution & $0(0.0 \%)$ \\
\hline Delayed & $1(1.7 \%)$ \\
\hline \multicolumn{2}{|l|}{ Personal-social skill } \\
\hline Advanced & $0(0.0 \%)$ \\
\hline Normal & $47(78.3 \%)$ \\
\hline Caution & $3(5.0 \%)$ \\
\hline Delayed & $10(16.7 \%)$ \\
\hline
\end{tabular}

${ }^{a}$ Normal indicates that the child is undergoing normal development with no delays for their age

${ }^{\mathrm{b}}$ Suspect indicates that there is a probability of the child undergoing delay in development for their age and are recomended to see an expert for re-screening

restricted access to good food resources, which leads to poor food composition in their diet, low food consumption, and even limited access to health services (Chua et al. 2018; Wong et al. 2014; Cheah et al. 2012). To add, as fishers were commonly poor, their household expenditure and unavailability of land for home agriculture activities, especially during monsoons, lead to minimal access to food. The same study by Cheah et al. (2012) discovered that other vital factors might affect these children's nutritional status, such as age, where younger children have a high prevalence of underweight, stunting and wasting. In contrast, older children and adolescents have a high prevalence of overweight and obesity. Other than that, the children's breastfeeding duration has significantly affected the prevalence of underweight, stunting, and wasting. Meanwhile, a mother's nutrition and low birth weight also impact children's nutritional status. Imbalanced feeding and low-energy diet food due to mothers' lack of nutrition education also play 


\section{Child development and nutritional status of children under five}

Table 3. Nutritional status of under five children in Terengganu $(\mathrm{n}=60)$

\begin{tabular}{|c|c|c|}
\hline Characteristics & $\begin{array}{c}\text { Distribution } \\
\mathrm{n}(\%)\end{array}$ & Mean \pm SD \\
\hline BMI-for-Age (z-score) ${ }^{*}$ & & $-1.62 \pm 1.23$ \\
\hline $\begin{array}{l}\text { Above } 3 \text { SD } \\
\text { (Obese) }\end{array}$ & $0(0.0)$ & \\
\hline $\begin{array}{l}\text { Above } 2 \text { SD } \\
\text { (Overweight) }\end{array}$ & $1(1.7)$ & \\
\hline $\begin{array}{l}\text { Above } 1 \text { SD } \\
\text { (Possible risk } \\
\text { of overweight) }\end{array}$ & $0(0.0)$ & \\
\hline $\begin{array}{l}0 \text { (Median) } \\
\text { (Normal) }\end{array}$ & $19(31.7)$ & \\
\hline $\begin{array}{l}\text { Below -1 SD } \\
\text { (Normal) }\end{array}$ & $18(30.0)$ & \\
\hline $\begin{array}{l}\text { Below -2 SD } \\
\text { (Wasted) }\end{array}$ & $14(23.3)$ & \\
\hline $\begin{array}{l}\text { Below -3 SD } \\
\text { (Severely wasted) }\end{array}$ & $8(13.3)$ & \\
\hline Height-for-Age (z-score) & & $-0.27 \pm 1.41$ \\
\hline $\begin{array}{l}\text { Above } 3 \text { SD } \\
\text { (Tallness) }\end{array}$ & $2(3.3)$ & \\
\hline $\begin{array}{l}\text { Above } 2 \text { SD } \\
\text { (Normal) }\end{array}$ & $1(1.7)$ & \\
\hline $\begin{array}{l}\text { Above } 1 \text { SD } \\
\text { (Normal) }\end{array}$ & $7(11.7)$ & \\
\hline $\begin{array}{l}0 \text { (Median) } \\
\text { (Normal) }\end{array}$ & $34(56.7)$ & \\
\hline $\begin{array}{l}\text { Below -1 SD } \\
\text { (Normal) }\end{array}$ & $12(20.0)$ & \\
\hline $\begin{array}{l}\text { Below -2 SD } \\
\text { (Stunted) }\end{array}$ & $3(5.0)$ & \\
\hline $\begin{array}{l}\text { Below -3 SD } \\
\text { (Severely stunted) }\end{array}$ & $1(1.7)$ & \\
\hline
\end{tabular}

a significant role in children's nutritional status. The children's appetite too impacted them as they consume low calorie that prevents their growth and development (Cheah et al. 2012).

A total of $6.7 \%$ of respondents were stunted or seriously stunted. Stunting is when the height-for-age of children is below -2SD of WHO growth standard z-score. Stunting is caused by prolonging insufficient consumption of nutritious food and a poor-quality diet that leads to a lack of nutrient intake (Mzumara et al. 2018). This result is somewhat counterintuitive because stunting is lower than in another Terengganu study (Wong et al. 2014), the national prevalence of stunting (13.4\%) (NHMS 2015), and Terengganu's prevalence of stunting (18.2\%) (NHMS 2015). This variance may be explained by variations in the number of respondents, geographic location, socioeconomic status (NHMS 2015; NHMS 2016b; Wong et al. 2014; Cheah et al. 2012), and the age range of the samples involved (NHMS 2016b). Geographical areas and various socioeconomic status are also the cause of the differences in the prevalence of wasting and stunting as this study only include fishermen communities, where other studies involved both rural and urban areas (NHMS 2015; NHMS 2016b; Wong et al. 2014; Cheah et al. 2012). Another reason for the differences in the broad age range of samples involved where this study only involves children aged 24 to 59 months, while other studies involve children aged 0 to 59 months (NHMS 2016b). This study has a lower percentage of stunting concerning other studies, primarily may due to higher accessibility to fish consumption. Fishes are an excellent protein source, Polyunsaturated Fatty Acids (PUFA), vitamins, and iodine. Protein and amino acids assist in tissue growth and development, while polyunsaturated fatty acids assist in vitamin A and $\mathrm{K}$ absorption. Iodine assists with the mental development of children's cognitive abilities (Mlauzi et al. 2017). More work needed to be done exploring the relationship between particular food group intake and its effects on reducing stunting prevalence.

\section{Association between nutritional status and child development}

The chi-square test for independence shows no significant association between BMI-for-age and child development, $\chi^{2}(1$, $\mathrm{n}=60)=0.167 ; \mathrm{p}=0.682 ; \mathrm{OR}=0.793$, meanwhile, there was also no association between height-forage and child development, $\mathrm{p}>0.001, \mathrm{OR}=0.919$, using Fisher exact test as shown in Table 4. The study has indicated that although wasting was prevalent, statistically, it was not evident that their nutritional status was associated with their overall development. This finding is contrary to previous studies which have suggested that better nutritional status leads to lower chances of developmental delay (Huiracocha-Tutiven et al. 2019; Hurley et al. 2016; Jimoh et al. 2018). 
Table 4. Association between nutritional status and overall development among children under five in Terengganu $(\mathrm{n}=60)$

\begin{tabular}{|c|c|c|c|c|c|}
\hline \multirow[b]{2}{*}{ Nutritional status } & \multicolumn{2}{|c|}{ Child overall development } & \multirow[b]{2}{*}{$\chi^{2}$} & \multirow{2}{*}{$\begin{array}{c}\text { Suspect } \\
\text { delay } \\
\text { OR }\end{array}$} & \multirow[b]{2}{*}{$\mathrm{p}$} \\
\hline & $\begin{array}{c}\text { Normal } \\
\mathrm{n}(\%)\end{array}$ & $\begin{array}{c}\text { Suspect } \\
\mathrm{n}(\%)\end{array}$ & & & \\
\hline \multicolumn{6}{|l|}{ BMI-for-age (ref: normal) } \\
\hline Normal & $26(70.3)$ & $11(29.7)$ & \multirow{2}{*}{$0.167^{\mathrm{a}}$} & \multirow{2}{*}{0.793} & \multirow{2}{*}{0.682} \\
\hline Not Normal & $15(65.2)$ & $8(34.8)$ & & & \\
\hline \multicolumn{6}{|l|}{ Height-for-age $^{\mathrm{d}}$ (ref: normal) } \\
\hline Normal & $37(68.5)$ & $17(31.5)$ & & \multirow{2}{*}{0.919} & \multirow{2}{*}{$1.000^{\mathrm{b}}$} \\
\hline Not normal & $4(56.7)$ & $2(33.3)$ & & & \\
\hline \multicolumn{6}{|c|}{${ }^{*}$ Significant at $\mathrm{p}<0.05 ; \mathrm{OR}=$ Odds Ratio } \\
\hline \multicolumn{6}{|c|}{${ }^{\mathrm{a}} 0$ cells $(0.0 \%)$ have expected count less than 5 ; The minimum expected count is 7.28} \\
\hline \multicolumn{6}{|c|}{${ }^{\mathrm{b}} 1$ cells $(50.0 \%)$ have expected count less than 5 ; The minimum expected count is 1.90 (thus, use Fisher exact test) } \\
\hline
\end{tabular}

This rather contradictory result may be due to the different instruments used, number of respondents, and age of respondents (Jimoh et al. 2018). Hence, it could conceivably be hypothesized that child development among fishermen's children between 24 to 59 months in Kuala Nerus and Kuala Terengganu were associated with other factors such as socioeconomic status, parental skills, stimulating environment and culture rather than nutritional status. Many constraints must be acknowledged. This research does not measure dietary intake, as this may add bias and complications. The respondents are young, and parents may not disclose their children's actual intake. As a result, further research is necessary to determine the viability of child development and its relationship to nutritional status. Future research would require a longer time span to create a complete image of child development growth, allowing for an in-depth examination of children's growth and development. In-depth investigations of each parameter are essential, as multiple factors influence various parameters of child growth.

This study has shed a contemporary light on the contentious issue highlighted in Nutrition Research Priorities (NRP) in Malaysia for 2016-2020 involving maternal and young child nutrition. This study should prove to be particularly valuable to the National Plan of Action for Nutrition for Malaysia, NPANM (2016-2025), as it demonstrates the prevalence of stunting and wasting for children under five in a vulnerable community. The NPANM goal is to have that prevalence of not more than $11 \%$ by 2025.

\section{CONCLUSION}

Around $30 \%$ of these children have been identified as having developmental delays. The majority of these children have a normal BMI and height for their age. In contrast to expectations, this study discovered no connection between child development and nutritional status of children under the age of five. As a result, further research is necessary to fully grasp child development and its relationship to nutritional status.

\section{ACKNOWLEDGEMENT}

This study was funded under the Fundamental Research Grant Scheme for Research Acculturation of Early Career Researchers (FRGS - RACER): RACER/1/2019/ SKK06/UMT//1. This study is part of a larger study "Risk assessments of low cognitive performance among fishermen's children in Terengganu, Malaysia”.

\section{AUTHOR DISCLOSURES}

The authors confirm that there are no known conflicts of interest associated with this publication. 


\section{REFERENCES}

Adnan N, Muniandy ND. 2012. The relationship between mothers' educational level and feeding practices among children in selected kindergartens in Selangor, Malaysia: A Cross-sectional Study. Asian J Clin Nutr 4(2):39-52. https://doi. org/10.3923/ajen.2012.39.52

Atiah MM, Asma' A. 2021. Dietary intake, nutritional status and cognitive performance among fishermen's children: A Review. Malaysian J Public Health Med 21(1):148-159. https://doi.org/10.37268/ $\mathrm{mjphm} / \mathrm{vol} .21 /$ no.1/art.1092

Bandoh DA, Manu A, Kenu E. 2018. Lacking in abundance: Undernutrition in a peri-urban fishing community in Coastal Ghana. BMC Nutr 4(1):1-7. https://doi.org/10.1186/ s40795-018-0229-8

Bradley RH, Corwyn RF. 2002. Socioeconomic status and child development. Annu Rev Psychol 53(1):371-399. https://doi.org/10.1146/annurev. psych.53.100901.135233

Capanzana MV, Aguila DV, Gironella GMP, Montecillo KV. 2018. Nutritional status of children ages $0-5$ and 5-10 years old in households headed by fisherfolks in the Philippines. Archive of Public Health 76(1):1-8. https://doi.org/10.1186/s13690018-0267-3

Cheah WL, Muda WAMW, Hussin ZAM, Thon CC. 2012. Factors associated with undernutrition among children in a rural district of Kelantan, Malaysia. Asia Pac J Public Health 24(2):330-342. https://doi. org/10.1177/1010539510380737

Chua HS, Ali A, Zakari NS, Yusof HM. 2018. Assessment of diet quality and its association with nutritional status among fishermen's children in Terengganu. Malays Appl Biol 47(6):137-144

Duarte MG, Duarte GSD, Nobre GC, Bandeira PFR, Santos JOLDS, Barros JLC. 2017. Motor development and associated factors in children between 36 and 42 months in low Amazon region. J Phys Educ 27. https:// doi.org/10.4025/jphyseduc.v27i1.2751

Eapen V, Zoubeidi T, Yunis F, Gururaj AK, Sabri S, Ghubash R. 2006. Prevalence and psychosocial correlates of global developmental delay in 3-year-old children in the United Arab Emirates. J Psychosom Res 61(3):321-326. https:// doi.org/10.1016/j.jpsychores.2006.05.012

[FAO] Food and Agriculture Organization. 2000. The Sate of Food Insecurity in The World 2000. Publishing and Multimedia Service, Information Division. Italy (IT): FAO.

Grantham-McGregor SM, Fernald LC, Kagawa RM, Walker S. 2014. Effects of integrated child development and nutrition interventions on child development and nutritional status. Ann N Y Acad Sci 1308:11-32. https://doi.org/10.1111/ nyas. 12284

Huiracocha-Tutiven L, Orellana-Paucar A, Abril-Ulloa V, Huiracocha-Tutiven M, Palacios-Santana G, Blume S. 2019. Child development and nutritional status in Ecuador. Glob Pediatr Health 6:p.2333794X18821946. https://doi. org/10.1177/2333794X18821946

Hurley KM, Yousafzai AK, Lopez-Boo F. 2016. Early child development and nutrition: A review of the benefits and challenges of implementing integrated interventions. Adv Nutr 2016 7(2):357-363. https:// doi.org/10.3945/an.115.010363

Jimoh AO, Anyiam JO, Yakubu AM. 2018. Relationship between child development and nutritional status of under-five Nigerian children. South Afr J Clin Nutr 31(3):50-54. https://doi.org/10.1080/1607 0658.2017.1387434

Khan S, Zaheer S, Safdar NF. 2019. Determinants of stunting, underweight and wasting among children <5years of age: evidence from 2012-2013, Pakistan demographic and health survey. BMC Pub Health 19(1):1-15. https://doi. org/10.1186/s12889-019-6688-2

Malaysian Open Data Portal. 2019. Bilangan penduduk negeri Terengganu mengikut umur. http://www.data.gov.my/data/ $\mathrm{ms}$ _MY/dataset/bilangan-penduduknegeri-terengganu-mengikut-kumpulanumur-2016 [Accessed 17th November 2019].

Mlauzi M, Mzengereza K. 2017. Contribution of fish consumption to reduction of malnutrition among the children under five in Salima, Malawi. J Anim Res Nutr 
2(2):18. https://doi.org/10.21767/25725459.100038

Mzumara B, Bwembya P, Halwiindi H, Mugode r, Banda J. 2018. Factors associated with stunting among children below five years of age in Zambia: Evidence from the 2014 Zambia demographic and health survey. BMC Nutr 2018 4(1):1-8. https:// doi.org/10.1186/s40795-018-0260-9

[NHMS] National Health and Morbidity Survey. 2016a. National Health and Morbidity Survey 2016: Maternal and Child Health. Volume 1: Methodology and General Findings. Kuala Lumpur (KL): Institute for Public Health, National Institutes of Health, Ministry of Health Malaysia.

[NHMS] National Health and Morbidity Survey. 2016b. National Health and Morbidity Survey 2016: Maternal and Child Health. Volume 2: Maternal and Child Health Findings. Kuala Lumpur (KL): Institute for Public Health, National Institutes of Health, Ministry of Health Malaysia.

[NHMS] National Health and Morbidity Survey. 2015. National Health and Morbidity Survey 2015: Non-Communicable Diseases Risk Factors \& Other Health Problems, Volume 2. Kuala Lumpur (KL): Institute for Public Health, National Institutes of Health, Ministry of Health Malaysia.

Pem D. 2015. Factors affecting early childhood growth and development: Golden 1000 days. Adv Practice Nurs 2015(1):101.

Rao N, Richards B, Sun J, Weber A, Sincovich A. 2019. Early childhood education and child development in four countries in East Asia and the Pacific. Early Child Res Q 2019 47:169-181. https://doi.org/10.1016/j. ecresq.2018.08.011

Rubio-Codina M, Attanasio O, GranthamMcGregor S. 2016. Mediating pathways in the socio-economic gradient of child development: Evidence from children 6-42 months in Bogota. Int J Behav Dev 40(6):483-491. https://doi. org/10.1177/0165025415626515

Sanusi NNNM, Ali A, Kamarudin KS, Yusof HM. 2018. Assessment of food insecurity and food coping strategies among fishermen household during monsoon in Terengganu, Malaysia. Malays Appl Biol 47(6):1-9.

Shong TS, Bakar SHA, Islam MR. 2018. Poverty and delinquency: A qualitative study on selected juvenile offenders in Malaysia. International Social Work 1-15. https:// doi.org/10.1177/0020872818756172

Treanor M. 2012. Impacts of poverty on children and young people. Stirling (UK): Scottish Child Care and Protection Network.

[UNICEF] United Nations Children's Fund. 2018. A study of urban child poverty and deprivation in low-cost flats in Kuala Lumpur. Malaysia (KL): UNICEF.

Valla L, Wentzel-Larsen T, Hofoss D, Slinning K. 2015. Prevalence of suspected developmental delays in early infancy: Results from a regional population-based longitudinal study. BMC Pediatr 15:1-8. https://doi.org/10.1186/s12887-0150528-z

Venetsanou F, Kambas A. 2010. Environmental factors affecting preschoolers' motor development. Early Child Educ J 37(4):319-327. https://doi.org/10.1007/ s10643-009-0350-z

Warsito O, Khomsan A, Hernawati N, Anwar F. 2012. Relationship between nutritional status, psychosocial stimulation, and cognitive development in preschool children in Indonesia. Nutr Res Pract 6(5):451-457. https://doi.org/10.4162/ nrp.2012.6.5.451

[WHO] World Health Organization. 1997. Global database on child growth and malnutrition. WHO. https://www.who.int/nutgrowthdb/ about/introduction/en/index 4.html [Accessed 29th November 2019].

[WHO] World Health Organization. 2006. Methods and development. France (FR): WHO Press, World Health Organization.

Wei TS, Ali A. 2018. Breakfast consumption and its relationship with cognitive performance among fishermen's children in Terengganu. Malays Appl Biol. 47(4):24-34.

Wong HJ, Moy FM, Nair S. 2014. Risk factors of malnutrition among preschool children in Terengganu, Malaysia: A case control study. BMC Pub Health 14(1):1-10. https://doi.org/10.1186/1471-2458-14-785

Zhang J, Guo S, Li Y, Wei Q, Zhang C, Wang X, Luo S, Zhao C, Scherpbier R W. 2018. Factors influencing developmental delay among young children in poor rural China: A latent variable approach. BMJ Open 8(8): p.e021628. https://doi.org/10.1136/ bmjopen-2018-021628 